\title{
Mathematics Online Teaching-Learning Methods, Advantages and Challenges during Covid-19: A Critical Study on Teachers and Learners
}

\section{T. Sangameshwar Rao}

Deputy Director (Academic), EMPC, Indira Gandhi National Open University, Maidan Garhi, New Delhi, India Corresponding author: rao.sangameshwar@gmail.com

\author{
Received: $13-09-2020$ \\ Revised: $25-11-2020$ \\ Accepted: 05-12-2020
}

\begin{abstract}
Subject like mathematics required constant teacher-student 2F2 engagement. Teacher writes mathematics formulas on blackboard and explains step by step while students try to understand the complex metrics hidden in the formulas. Teacher also observes the facial expressions of students and clear doubts instantly. But during Covid-19, whole world is compelled to teach all subjects online. As of today many online platforms are available for mathematics, but the ground reality is, the majority of teachers and students not only prepared for online teaching learning but also not having the knowledge of online apps and software to use it. This study critically examines how online mathematics teaching-learning processes facilitated with available digital gadgets, used via internet without any proper training. Further examines what kind of challenges and advantages experience by online teacher-learner respondents. This study also gathered opinions about tailor made apps from teachers and learners those who have tried. The outcome of this research study indicates positive valid suggestions to improve online teaching-learning strategies as experienced by the different respondents. The study suggest that there is urgent need to develop and offer free orientation training programs by Digital India initiatives to primary, secondary, senior secondary and higher level students.
\end{abstract}

Keywords: A/Synchronous, apps, online, screen-sharing, webcam, F2F, digital gadgets

Before covid-19 Indian government statutory professional bodies, denied the permission for technical and practical nature courses, which involved lab practical, were not allowed to offer by ODL or online mode. But during in covid-19 entire courses are offered online. It is said necessary is the mother of invention, teachers-learners have innovated their own ways and means to teach mathematics, those who have the knowledge and those who do not have the knowledge of teachinglearning online software and apps. The subject like mathematics required direct face to face (F2F) live interaction and dialogue between teacher and students. It is mandatory to have a physical blackboard and teacher who writes mathematical formulas and students have to watch it carefully to understand the hidden concepts of the formulas. But online teaching and learning is not a new concepts, privately run by many online institutes like Khan Academy, Uncademy, Topper TV channel and also government ODL universities, etc. successfully offering mathematics courses. But teachers and students should be well trained and oriented as how to use the software.

\section{Review of Literature}

On the other hand, online learning is not a new

How to cite this article: Rao, T.S. (2020). Mathematics Online TeachingLearning Methods, Advantages and Challenges during Covid-19: A Critical Study on Teachers and Learners. Educational Quest: An Int. J. Edu. Appl. Soc. Sci., 11(4): 175-181.

Source of Support: None; Conflict of Interest: None 
concept; many research studies proved learning mathematics can be successfully taught on Radio with audio vision format. Nicaraguan government ran five years radio mathematics project in 1973 developed by Mathematical Studies in the Social Sciences funded by United States Agency for International. The project was successfully taught mathematics via radio broadcast from 1974-1979 after that Nicaraguan staff assumed responsibility (Friend, J. 1980). In Thailand in 1982, one time expenditure programmes were made to teach mathematics on audio tapes is proved to be very cost effective and students felt ease of learning with step by step with their own learning pace. Each student was supplied with audio cassettes and teachers notes. Learners have to play pause play mode to listen the mathematics problem solving methods (Sang-Jan 1982). Reading and writing mathematical formulas are entirely different than reading social science text; moreover it is much more challenging to teach mathematics to blind students. Very slow paced audio tapped programmes supplied with brail text giving guidance made available to blind learners. This effort given yielding results in teaching mathematics to blind learners (Karshmer, 2002). Jaun and others mentioned in their research studies, says online teaching mathematics uses blended learning techniques which show successful collaborative learning methods such as discussion forums, chats, e-mails, shared workspaces, lists of frequently asked questions and frequent errors, etc. (Juan, 2011). Khan Academy taught mathematics online for $9^{\text {th }}-10^{\text {th }}$ grade students by providing one to one mobile device in three rural areas schools, Adams High School, Jefferson High School and Washington High School. Online teaching was measured on the basis of theoretical, pedagogical, and content Knowledge and shown improvement on students (Dickinson, 2016). The research study conducted on 60 preschool and elementary school mathematics teachers based on independent as well as collaborative learning with experimental designs (Tezer, 2019). The study indicates positive results based on pre-test and after test methods adoption was blended online teaching practices with the use of ICT digital technologies.

\section{Problem of the Study}

Even though there are plenty of online tutorials offering online mathematic classes like Khan Academy, Unacademy, Byjus, WebEx, Cisco, Bitpaper, Zoom, Scribblar, MyTutoring Tutortrove with interactive white board supported and Talent LMS, Skype, Wacom are without interactive whiteboard integrated. Some apps for instant problem solving like Snap shot, Snap Solve and many more specific online programs to deal with different mathematic topics like Algebra, Abstract Algebra, Vector Algebra, Geometry, Coordinate Geometry, 3D Geometry, Linear Programming, Probability Theory, Calculus, Vectors, Real Analysis, Mensuration, Statistics and Probability claims with the help of these software mathematics can be taught and learnt with ease. But the ground reality is majority of the teachers and learners were not prepared for online teaching-learning prior to covid-19 lockdown. The biggest challenge is both teachers and learners have not even exposed or trained on any of the above online tailor made software. It is mandatory for subject like mathematics both teacher and learner should be familiar with the software how to use it. Besides this problem, non-availability of high speed uninterrupted internet, high resolution camera reception, good bandwidth to share good quality two-way audio and video which facilitates teacher and student can look and interact with each other during the class, also posing a major problem.

\section{Scope of the Study}

This study reveals the mirror image of the real life situation as how online teaching-learning mathematics facilitated to various age groups during covid-19. How various electronic digital gadgets were put into use for an effective two way interaction as well as screen sharing of mathematics formulas between teacher and students? The study also analysed the opinions of online trained vs nontrained teachers-students experiences.

\section{Objectives of the study}

1. To study the problems, issues and challenges faced by mathematics teachers and students.

2. To study the online methods being adopted by the mathematics teachers and students.

3. To study the need assessment of mathematics teachers and students for present and future. 


\section{Methodology}

The study focused on to obtain, how online teaching-learning mathematics adoption during COVID-19. This study included teachers-learners from a wide range of educational background.

Starting from, $8^{\text {th }}$ class at primary level to secondary, senior secondary and went on to up to Ph.D. level teachers and students, study methods; irrespective of government or private institutes.

The study relied on both secondary data and primary data. Survey method is employed to get the opinions of Teachers as facilitators and end users as learners' perspectives on Technologyenabled teaching learning through online. The survey has proceeded through the self-administered questionnaire.

A sample of 101 respondents taken by using a snowball sampling method, that includes 87 students out of which female 42 and male 45 student respondents. The student's age is ranging from 9 to 30 years. 14 teacher respondents, includes 5 female teachers, 7 male teachers and 1 third gender teacher. The teacher's age is ranging from 25 to 65 years. The study also considered gender as one of the essential variables for the study. Sampling also including the third gender respondents who ever mentioned.

\section{Tool for data collection}

A Questionnaire developed by the researcher and validated by the experts is used for collecting the data from the respondents. A total of 21 questions include both open-ended and close-ended questions. 10 questions each for teachers 10 questions for students one 1 common question for both teachers and students are designed. Questions are uploaded on Google forms and distributed through sharing the hyper link through email and WhatsApp medium to reach the respondents.

\section{Analysis}

The total respondents are 101 out of which 87 students who are learning mathematics online with age groups varying from 9 to 30 years, studying in different classes from primary, secondary, senior secondary, certificate courses, diploma courses, B.Sc/Hons mathematics, M.Sc., Mathematics/ computer application. The espondents are both from government and private institutions. Some of them attended their normal regular classes, while others attended private online courses and already familiar with online software and know how to use it.

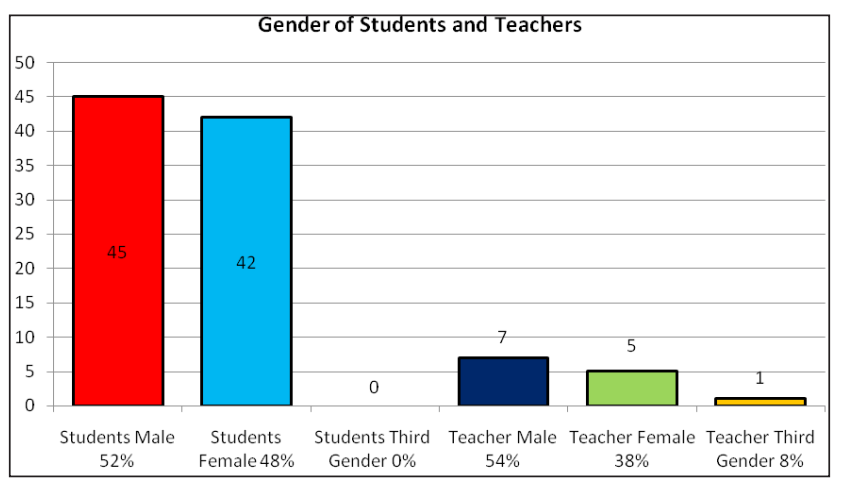

Chart 1: Showing Online Mathematics Student \& Teacher Gender

Total 87 students responded out of which the genders consisting of 45 male and 42 Female and no third gender student responded their age varies from 9 to 30 years, starting from $8^{\text {th }}$ class to Ph.D. level. Students responded are taking regular classes, online classes form online learning apps, preparing for competitive exams like IIT JEE, JAM, GATE and also students who are trying online apps apart from their regular classes participated in this survey.

Teacher 14 respondents whose age group ranging from 25 to 65 years. Among 14 teachers gender are 7 male, 5 female and 1 prefer not to say. Teachers teaching from class 8 to primary, secondary, senior secondary, certificate courses, diploma courses, coaching for competitive exams like, IIT entrances tests, IIT JAM, IIT GATE, IIT JEE, B.Sc., Hons, mathematics, Computer applications, M.Sc., Mathematics and Computer applications and up to Ph.D. level students

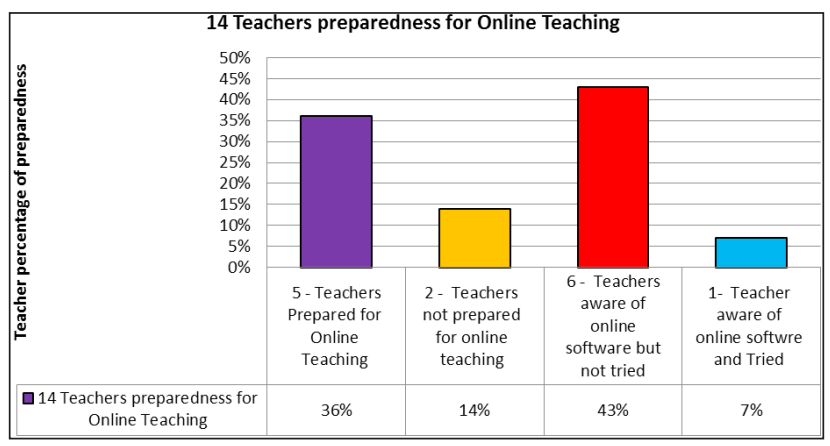

Chart 2: Showing 14 Teachers Preparedness for online Teaching before Covid-19 lockdown

Analysed 14 mathematics teacher's preparedness for online teaching before covid-19 locked, among 
that 5 teachers were prepared for online teaching. 2 teachers said that they were not prepared before covid-19 lockdown. 6 teachers said even though they were aware of online mathematics teaching software but they admitted not tried before covid19 lockdown. 1 teacher said he is not only aware but also familiar before covid-19 lockdown. The above situation shows that the majority of the teachers are not prepared for the online teaching; their trial and error method caused anxiety among teachers and students. Because, subject like mathematics teaching-learning communication process, should go on systematically in-between teachers - interactive bridge as blackboard or interactive whiteboard end user students.

Total 79 students responded for analysis about their preparedness for online learning beofre covid19. Among those 36 students who are having regular school mathematics classes expressed that they were not prepared for online classes. 22 students said that they were prepared before covid19 for online classes. 18 students said even though that they were aware and heard of online classses and available corresponding software for different subjects but they have not tried any of them. It means they cannot operate or use for learning. 10 students said that they are completely aware of the software and learnt during covid19. Interestingly $10+2$ students who are preparing for competetive exams, B.Sc., M.Sc., and Ph.D level students tried the tailor made online learning apps and realised its real potentials. But the very few students who have tried these tailor made learenig apps to learn geometry, coordinate geometry, 3 geometry, algebra, abstract algebra, computer application applications programs and so on.

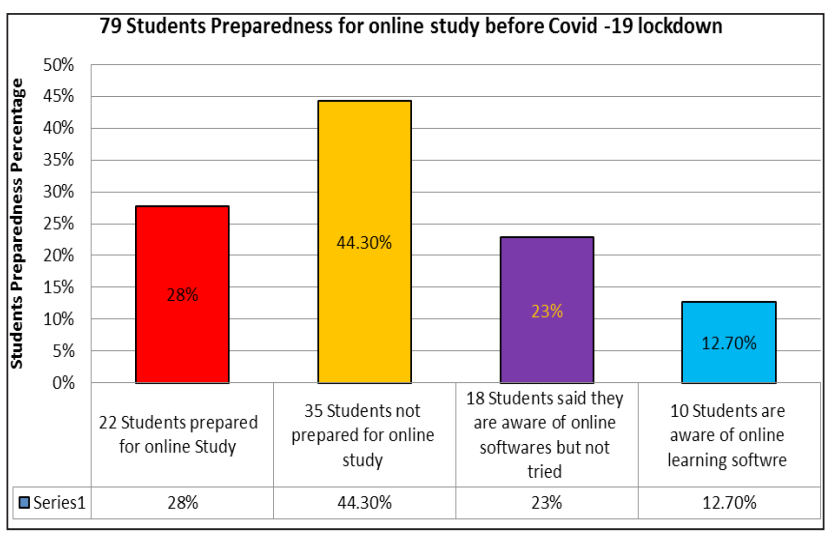

Chart 3: Showing 79 Students Preparedness for online study before Covid -19 lockdown
Table 1: Showing 14 Teachers Tried ICT tools for Teaching Mathematics before covid-19

\begin{tabular}{lcc}
\hline $\begin{array}{l}\text { Teachers Tried Some of } \\
\text { these online teaching ICT } \\
\text { tools }\end{array}$ & $\begin{array}{c}\text { No. of } \\
\text { Teachers }\end{array}$ & Percentage \\
\hline Programmable Toys & 1 & $8.3 \%$ \\
$\begin{array}{l}\text { Desktop Publishing } \\
\text { Interactive Whiteboards }\end{array}$ & 1 & $8.3 \%$ \\
$\begin{array}{l}\text { Spreadsheets } \\
\text { Mathematic Teaching apps }\end{array}$ & 1 & $50 \%$ \\
$\begin{array}{l}\text { No I have not tried any } \\
\text { software }\end{array}$ & 1 & $8.3 \%$ \\
$\begin{array}{l}\text { Databases } \\
\text { Before covid -19 I have not } \\
\text { tried any ICT tools }\end{array}$ & 1 & $8.3 \%$ \\
$\begin{array}{l}\text { Yes I have Tried some of the } \\
\text { above ICT tools }\end{array}$ & 1 & $8.3 \%$ \\
\hline
\end{tabular}

When questioned what are the ICT online tools as a teacher of mathematics they have tried to teach mathematics online. 14 teachers said that they have tried different software like programmable toys, desktop publishing, interactive whiteboards, spreadsheets, mathematics teaching apps, data bases. Among all these software it is also revealed by the teachers that the interactive whiteboard is very useful for teaching mathematics online. Nowa-days lots of online tutoring mathematics software are integrating interactive whiteboard. Some such, software like WizTQ, Cisco WebeX, Zoom, Bitpaper, Scibblar, mytutoring, Tutor Trove integrate 'Interactive Whiteboard in-built in their software.

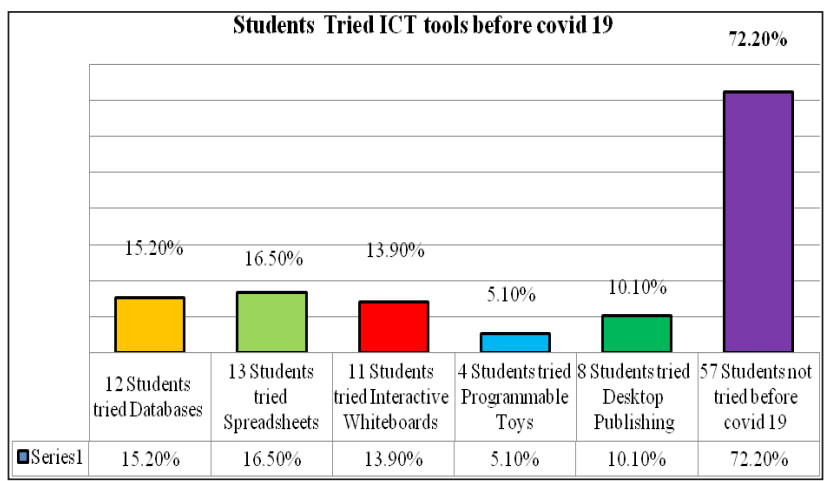

Chart 4: Showing 79 Student Tried ICT tools for Learning Mathematics before Covid-19

Students were asked what ICT tools they have tried before covid19 to learn the mathematics online. 57 students said they have not tried any ICT tools before covid19, they are mostly students belongs 
to class 8 to 10 class who are attending regular school classes. 12 students have tried databases, 13 students have tried spreadsheets, 11 students have tried interactive whiteboard, 4 students tried programmable toys, and 8 students have tried desktop publishing. It is found those who have tried the these ICT tools are preparing for their competitive exams like IIT JEE, GATE, JAM or doing B.Sc and .M.Sc mathematics and computer application students.

Table 2: Showing Problems faced by 14 Teachers while online teaching Mathematics

\begin{tabular}{|c|c|c|}
\hline Problems Faced by Teachers & $\begin{array}{l}\text { Numbers } \\
\text { of Teachers }\end{array}$ & Percentage \\
\hline $\begin{array}{l}\text { Unable to see all students just } \\
\text { like in a classroom }\end{array}$ & 6 & $50 \%$ \\
\hline $\begin{array}{l}\text { Difficulty in Organizing Online } \\
\text { students groups }\end{array}$ & 2 & $16.7 \%$ \\
\hline $\begin{array}{l}\text { Engaging students from } \\
\text { different background }\end{array}$ & 3 & $25 \%$ \\
\hline $\begin{array}{l}\text { Difficulty in bringing all } \\
\text { students at same level of } \\
\text { understanding }\end{array}$ & 3 & $25 \%$ \\
\hline $\begin{array}{l}\text { Selecting appropriate online } \\
\text { tools for mathematics specific } \\
\text { technology }\end{array}$ & 4 & $33.3 \%$ \\
\hline $\begin{array}{l}\text { Getting students to use online } \\
\text { technology or selected software } \\
\text { properly }\end{array}$ & 3 & $25 \%$ \\
\hline $\begin{array}{l}\text { Getting familiarity of the } \\
\text { selected software by both teacher } \\
\text { and learner }\end{array}$ & 1 & $8.3 \%$ \\
\hline Poor quality camera & 3 & $25 \%$ \\
\hline $\begin{array}{l}\text { Weak signal, poor internet } \\
\text { quality }\end{array}$ & 6 & $50 \%$ \\
\hline $\begin{array}{l}\text { Lack of proper clarity two way } \\
\text { interaction }\end{array}$ & 2 & $16.7 \%$ \\
\hline Students use different devises & 3 & $25 \%$ \\
\hline $\begin{array}{l}\text { Students most of the time switch } \\
\text { off the camera/video output }\end{array}$ & 3 & $25 \%$ \\
\hline $\begin{array}{l}\text { As teacher we need more } \\
\text { training to use software before } \\
\text { teaching }\end{array}$ & 5 & $41.7 \%$ \\
\hline $\begin{array}{l}\text { No I did not faced any of these } \\
\text { problems I am aware of the } \\
\text { software use }\end{array}$ & 1 & $8.3 \%$ \\
\hline $\begin{array}{l}\text { Yes agree I have faced some of } \\
\text { the above problems }\end{array}$ & 2 & $16.7 \%$ \\
\hline
\end{tabular}

This is one of the crux issues of online teaching problems faced by teachers while online teaching mathematics. The issues can be categorized into three segments are psychological, technical and practical issues. Subject like mathematics require constant F2F communication via word of mouth and with the help of blackboard or digital interactive white board. Students watch teacher while writing formulas and explain the hidden meaning in the formulae. Problem of bringing all the students at the same level of understanding, enable to see all the students by the teacher while explaining formulae so that he or she can observe the slow learners and clear his or doubts would help the students to move on with peers and also understand the formula discussed. The third issue of technical nature that uninterrupted high speed internet good signal is essential, effective screen sharing methods are necessary for successful online teaching. The above problems clearly indicate for successful online teaching knowledge of online software is essential teachers.

Table 3: Showing Problems faced by 80 Students while learning Mathematics online

\begin{tabular}{|c|c|c|}
\hline Problems Faced by Students & $\begin{array}{c}\text { Numbers of } \\
\text { Students }\end{array}$ & Percentage \\
\hline Unable to meet my peer group & 28 & $35 \%$ \\
\hline $\begin{array}{l}\text { Unable to fit in Online peer/ } \\
\text { fellow students groups }\end{array}$ & 8 & $10 \%$ \\
\hline $\begin{array}{l}\text { Unable to follow with the same } \\
\text { speed with all other students }\end{array}$ & 17 & $21.3 \%$ \\
\hline $\begin{array}{l}\text { Selected online software tools for } \\
\text { mathematics i am not familiar }\end{array}$ & 8 & $10 \%$ \\
\hline $\begin{array}{l}\text { I require more practice on the } \\
\text { software tool before actual } \\
\text { learning }\end{array}$ & 12 & $15 \%$ \\
\hline $\begin{array}{l}\text { We both teacher/ students are } \\
\text { not familiar with the selected } \\
\text { software }\end{array}$ & 8 & $10 \%$ \\
\hline Very Poor quality camera & 10 & $12.5 \%$ \\
\hline $\begin{array}{l}\text { Signal break due to weak internet } \\
\text { signal. }\end{array}$ & 53 & $66.3 \%$ \\
\hline $\begin{array}{l}\text { Lack of proper screen sharing } \\
\text { while writing mathematics } \\
\text { formulas }\end{array}$ & 16 & $20 \%$ \\
\hline $\begin{array}{l}\text { Selected software tools is not } \\
\text { properly used or explored. }\end{array}$ & 9 & $11.3 \%$ \\
\hline $\begin{array}{l}\text { We require more training on the } \\
\text { software }\end{array}$ & 16 & $20 \%$ \\
\hline $\begin{array}{l}\text { No I did not faced any of these } \\
\text { problems I am aware of the } \\
\text { software use }\end{array}$ & 5 & $6.3 \%$ \\
\hline
\end{tabular}


Table 4: Gadgets Preferred and used for online teaching mathematics by teachers and learners

\begin{tabular}{|c|c|c|c|c|}
\hline $\begin{array}{l}\text { Total } 13 \text { Number of } \\
\text { Teachers }\end{array}$ & Percentage & Gadgets Preferred & $\begin{array}{l}\text { Total } 79 \text { Number of } \\
\text { Students }\end{array}$ & Percentage \\
\hline 4 & $30.8 \%$ & High resolution camera with Blackboard & & \\
\hline 2 & $15.4 \%$ & Desktop with Webcam & 6 & $7.6 \%$ \\
\hline 10 & $76.9 \%$ & Laptop with webcam & 23 & $29.1 \%$ \\
\hline 0 & $0 \%$ & PDA & 1 & $1.3 \%$ \\
\hline 2 & $15.4 \%$ & Mobile Phone & 25 & $31.6 \%$ \\
\hline \multirow[t]{3}{*}{2} & $15.4 \%$ & Tablet & 15 & $19 \%$ \\
\hline & & Desktop & 12 & $15.2 \%$ \\
\hline & & Laptop & 35 & $44.3 \%$ \\
\hline
\end{tabular}

Students also expressed the mixed nature of problems based on psychological, cognitive and technology mediated issues related to online mathematics learning. Students mentioned that they are unable to see and catch up the same speed with their peers while learning. Poor quality camera, frequent power cuts, weak signal, ineffective screen sharing are one of the pivotal issues. This proves the fact students should also have the knowledge of how to use the online software to keep up with their teacher.

Online teaching learning mathematics is completely technology mediated process if it is professionally taught in a controlled situation i.e. professional institutes who are conducting online classes like Khan Academy, Unacademy, Topper TV, it is understood where both teachers and learners are pre-oriented on online software to be used for their teaching-learning methods during their course of study. But during Covid-19 lockdown suddenly online teaching-learning imposed, without any prior notice or training to teachers and learners. Online learning cannot be facilitated without proper use of digital communication gadgets. The below chart shows what are digital gadgets preferred and used by teachers and learners for teaching-learning online mathematics.

Teachers and Learners have used digital gadgets available with them and also they felt ease on using. Here the main factor, what we need to consider is the affordability and availability of the gadgets by the learners. We can find majority of the students and learners used laptop with webcam. Many learners who cannot afford to have the above gadgets depended upon public broadcast television all Doordarshan Kendras, ran by each state government (Rao T.S., 2020). Online teaching was imposed all of sudden without prior notice by the government for entire nation. Above facts reveals majority of the teachers are not familiar with online tailor-made software.

Chart 5: Showing How Teaches managed online teaching without tailor made Teaching apps

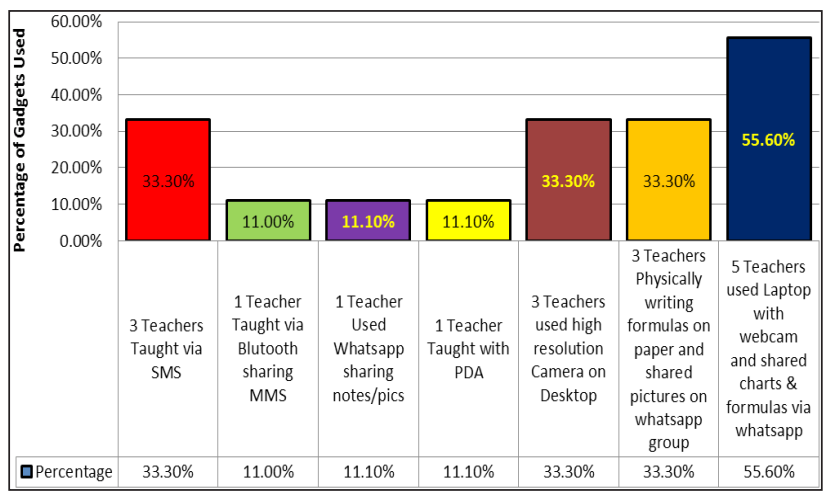

The study reveals majority of the teachers managed their teaching in a best possible way by using Laptop with webcam as two-way audio and video bridge, and for sharing formulas writing on paper or notebook, the pics via WhatsApp group, Bluetooth and PDA.

Table 5: Showing Online Teaching-Learning can be Successful or Not if provided Training on online Teaching-Learning software - Agreement of Teachers and Learners

\begin{tabular}{lll}
\hline Agreement & $\begin{array}{l}\text { Total Number of } \\
\text { Teachers 12 }\end{array}$ & Percentage \\
\hline Strongly Disagree & 1 & $8.3 \%$ \\
Disagree & 1 & $8.3 \%$ \\
Neutral & 3 & $25 \%$ \\
Agree & 5 & $41.7 \%$ \\
Strongly Agree & 2 & $16.7 \%$
\end{tabular}


The subjects like mathematics can be effectively taught with the help of tailor-made learning apps, complex-abstract formulae can be easily explained with $3 \mathrm{D}$ graphics and animation, the author having 25 years of experience in making educational teaching documentaries using technology mediated lessons substantiate the idea of successful online teaching. Here majority of the teachers agreed especially those who have the knowledge of online teaching apps and those who learnt and experienced its advantages of online technology mediated teaching and learning possibilities agreed and strongly agreed comes to $58.4 \%$. The author strongly recommends successful online teaching if proper use of 3D animations, suitable tailor-made subject wise teaching software, interactive whiteboards, real-time peer interaction, high resolution camera mathematics can be more effectively taught than a conventional classroom.

\section{Teachers Suggestions for Effective Online Teaching Mathematics}

Teacher's respondents expressed that the online teaching is entirely different than traditional classroom teaching and learning. Training on effective use of tailor made mathematics software for teachers is necessity. It will help a great extent to primary as well as higher education learners. Apart from training, high speed uninterrupted internets, high resolution camera also important for effective online teaching to sustain two way interactivity.

\section{Students Suggestions for Effective Online Teaching Mathematics}

Student's respondents suggested that the online teachers should not be in hurry while teaching. Knowledge of tailor made mathematics programs is necessary to for both learners and teachers. Interactive white boards and effective screen sharing methods should be more effectively explored, without that teaching and learning mathematics cannot be successful. All the learners should be provided personalized training, as how to use, various tailor made online mathematics software.

\section{CONCLUSION}

Based on responses the study revealed very positive opinions for online teaching learning. The government of India under Digital India Initiatives, and Department of Elementary, Primary Secondary, Senior Secondary and Higher Education (Ministry of Human Resource Development) should develop Mathematics online teaching-learning software and give free orientation and training as how to use it to teacher-learner communities. Budget provisions should be made for all Educational Media Units to establish 3D animation units for teaching and learning purposes.

\section{REFERENCES}

Dickinson, B.D. 2016. One-to-one mobile devices in rural school districts: A mixed methods study investigating the impact of Khan Academy on mathematics achievement and teacher pedagogy (Doctoral dissertation, Northwest Nazarene University).

Friend, J. 1980. Radio Mathematics in Nicaragua.

Juan, A.A., Steegmann, C., Huertas, A., Jesus Martinez, M. and Simosa, J. 2011. Teaching mathematics online in the European Area of Higher Education: an instructor's point of view. International Journal of Mathematical Education in Science and Technology, 42(2): 141-153.

Karshmer, A.I. Bledsoe, C. 2002. Access to mathematics by blind students. In International Conference on Computers for Handicapped Persons (pp. 471-476). Springer, Berlin, Heidelberg.

Rao, T.S. 2020. Issues and Challenges of Online ODL Courses: Case study of SWAYAM Stakeholders. Mukt Shabd Journal, 9(6): 3303.

Sang-Jan, P. 1982. Media and the Teaching of Mathematics in Thailand. Media Asia, 9(4): 203-205.

Tezer, M., Yildiz, E.P., Bozkurt, S. and Tangul, H. 2019. The influence of online mathematics learning on prospective teachers mathematics achievement: The role of independent and collaborative learning. World Journal on Educational Technology: Current Issues, 11(4): 257-265. 
